\title{
Resource Use Efficiency Among Aerobic and Conventional Rice Farms in Eastern Dry Zone of Karnataka: A Comparative Analysis
}

\author{
Thejaswi Kumar, J.", Lokesha, H. and Samjhauta Thapa
}

Department of Agricultural Economics, UAS, Bangalore, Karnataka, India

*Corresponding author: thejaswi3596@gmail.com (ORCID: 0000-0002-4820-0103)

Received: 06-06-2021

Revised: $15-08-2021$

Accepted: 03-09-2021

\begin{abstract}
The efficiency with which farmers use available resources is very important for agricultural production. This study examines the comparative resource use efficiency (RUE) between aerobic and conventional rice farms in Eastern Dry Zone (Zone-5) of Karnataka. Cross-sectional data were collected from 100 rice cultivating farmers (50 in Aerobic farms and 50 in Conventional farms) using snow ball sampling technique. Cobb-Douglas production function, Marginal analysis of resource utilization, Data Envelopment Analysis (DEA) were some of the analytical tools used in the study. The mean aerobic farm size was 0.43 ha while in Conventional rice, it was 0.63 ha. The physical water use efficiency (WUE) in aerobic farms (3.84 q/ acre inch) was higher than conventional farms (1.64 q/acre inch). Also, the economic WUE was higher in aerobic farms (1643.54 ₹/acre inch) compared to conventional farms (269.41 ₹/acre inch). RUE indicated that, resources were not optimally utilized in both Aerobic Rice Cultivation (ARC) and Conventional Rice Cultivation (CRC). Bullock labour, machine labour, seeds and irrigation were underutilized in ARC, whereas, FYM was underutilized in CRC indicating that usage of additional amount of these inputs leads to increase in the returns. The DEA revealed that aerobic rice cultivating farms were more technically and economically efficient compared to conventional rice cultivating farms. Effective policies to promote and create awareness about aerobic rice can boost the rice production and productivity sustainably. The focus should be given to optimal allocation of resources which enhances the farm productivity and returns.

\section{Highlights}

( Aerobic rice cultivation exhibits higher physical and economic water use efficiency compared to conventional rice cultivation. The production function shows the scope for optimal utilization of resources for profit maximization.

(- Aerobic rice farms are efficient compared to conventional rice farms in terms of allocation of resources. Hence, where economically efficient.
\end{abstract}

Keywords: Aerobic rice, resource use efficiency, sustainable production, production function, physical and economic water use efficiency

Rice (Oryza sativa L.) is India's most significant cereal crop. It accounts for approximately 23.3 percent of the country's gross cultivated area and is a significant staple food for approximately 65 percent of the Indian population (Joshi et al. 2018). Rice accounts for 43 per cent of total food grain production and 46 per cent of overall cereal production in the country. India has the world's largest rice acreage and ranks second in production among rice-growing countries (FAO 2018). Given the increase in rice output and human population growth over the last decade, there is an urgent

How to cite this article: Thejaswi Kumar, J., Lokesha, H. and Thapa, S. (2021). Resource Use Efficiency Among Aerobic and Conventional Rice Farms in Eastern Dry Zone of Karnataka: A Comparative Analysis. Economic Affairs, 66(3): 439-446.

Source of Support: None; Conflict of Interest: None 
need to raise rice production by 70 per cent to meet future demand by 2050. (Schroeder et al. 2013). In Karnataka, rice is grown in an area of 14.70 lakh hectare, with an average production of 35.20 lakh ton, with a productivity of $2996 \mathrm{~kg} / \mathrm{ha}$. About 55-60 per cent of the rice is grown under puddled system and the rest is under rainfed situation (UASB, 2020).

Traditional rice cultivation is labour-intensive which is well- suited to regions with low labour cost and high rainfall (Jayasree et al. 2021). Irrigated rice is typically transplanted into puddled paddy fields, which includes land preparation with 4-6 inches of standing water (Singh et al. 2021). The fresh water resources for rice production are limited because of increased competition of accelerated urbanization and industrial development. Hence, the need for "more rice with less water" is the need of the hour for global food security (Maneepitak et al. 2019). Thus, efficient use of irrigation water is crucial for sustainable rice production.

The dwindling water resources reveal a grim situation for conventional rice cultivation. Because of increasing water scarcity, there is a need to develop alternative rice ecosystems that require less water (Bouman et al. 2002). To keep up the rice production during irrigation water shortage, alternate methods of cultivation of rice is essential (Shailaja and Shivashankar, 1985). One such strategy is cultivation of rice under aerobic situation (Venkataravana, 1991). Aerobic rice is a promising rice cultivation system for managing water and growing rice under water-limited conditions, reduce water losses and increasing water productivity (Nie et al. 2007). Aerobic rice usually grown in upland conditions in unpuddled soil with nonflooded conditions, i.e., unsaturated (aerobic) soil with less water requirement (Bouman et al. 2006; Joshi and Kumar, 2012). Under these conditions, the cultivation of high-yielding aerobic rice helps to save water. New varieties specially bred for this situation are most suitable for such cultivation and withstand intermittent drought spells with minimum yield loss with maximum potential of 6 tons per hectare (Shailaja, 2008). The amount of methane emitted under aerobic situation is very low and contributes to lowering of greenhouse gas emission (Shailaja, 2008).

The sustainability of rice-based farming systems are threatened by sub-optimal use of inputs, increasing resource scarcity, especially water and labour, climate change, emerging energy crisis and rising fuel prices, the rising cost of cultivation and emerging socio-economic changes such as urbanization, migration of labour, preference for non-agricultural activities etc., (Ladha et al. 2009). The study mainly focuses on assessing the efficiency of new novel aerobic rice variety, MAS-26, released by University of Agricultural Sciences, Bangalore in comparison with the conventional rice varieties. The paper also presents the comparative analysis of economic and physical water use efficiency (WUE). Hence, the paradigm shift in method of rice cultivation plays pivotal role in addressing the issues related to sustainable rice cultivation.

\section{MATERIALS AND METHODS}

\section{Sampling framework}

The aerobic rice varieties were released and distributed exclusively for Eastern dry zone of Karnataka, hence, this region was selected purposively for the study. In the preliminary survey, sufficient number of farmers were found practicing Aerobic Rice Cultivation (ARC) as well as Conventional Rice Cultivation (CRC) under borewell irrigation and this was also other reason for selection of the study area. Snow ball sampling technique was adopted for selection of sample respondents, since, it was difficult to locate aerobic rice cultivating farmers. A sample size of 100 farmers were selected equally practicing ARC and CRC.

\section{Analytical framework}

\section{Economic and physical water use efficiency}

Resources being scarce and the opportunity for adoption of superior technologies are competitive, efficient use of such scarce resource is the need of hour (Ashok, 2018). Water being such a scarce resource in Eastern dry zone of Karnataka, measuring its efficiency is crucial for the adoption of novel improved technologies. The Physical and Economic WUE are calculated as follows;

$$
\begin{aligned}
& \text { Physical WUE }=\frac{\text { Output }(q / \text { ha })}{\text { Water used }(\text { acre inches } / \text { ha })} \\
& \text { Economic WUE }=\frac{\text { Net returns }(\text { Rs } / \text { ha })}{\text { Water used }(\text { acre inches } / \text { ha })}
\end{aligned}
$$


Where,

Output is in quintals per hectare (q/ha)

Water measured in acre inches per hectare (acre inches/ha)

Net returns in rupees per hectare $(₹ / h a)$

\section{Resource use efficiency}

Cobb-Douglas production function (per farm) was employed to analyze the resource use efficiency in ARC and CRC. The specification of the model for rice production under ARC and CRC is given as,

$$
Y=a X_{1}^{b_{1}} X_{2}^{b_{2}} X_{3}^{b_{3}} X_{4}^{b_{4}} X_{5}^{b_{5}} X_{6}^{b_{6}} e^{u}
$$

Where,

Dependent variable, $Y=$ Gross returns $(₹ /$ farm)

Independent Variables,

$X_{1}=$ Human labour (man days/farm)

$X_{2}=$ Bullock and machine labour cost (₹/farm)

$X_{3}=$ Seeds $(\mathrm{Kg} /$ farm $)$

$X_{4}=$ FYM (Tractor load/farm)

$X_{5}=$ Fertilizers (₹/farm)

$X_{6}=$ Irrigation $(₹ /$ farm $)$

$a=$ Constant

$u=$ Random variable

$b_{5}$ to $b_{6}$ indicate regression coefficients of inputs and implicitly represents the elasticity of production of respective inputs. The equations were transformed into the logarithmic form (log linear).

\section{Marginal Value Product (MVP)}

The estimates were used to calculate the MVP. By assessing the marginal value product of factors, we can estimate their relative importance. MVP of $X_{i^{\prime}}$ the $i^{\text {th }}$ input is assessed by using the following formula,

$$
M V P=b_{i} \times \frac{G M(Y)}{G M\left(X_{i}\right)}
$$

Where, GM $(Y)$ and $G M\left(X_{i}\right)$ signify the geometric mean of output and input respectively and $b_{i}$ is the regression co-efficient of $i^{\text {th }}$ input.
The model estimation gives,

$$
r=\frac{M V P}{M F C}
$$

Where, $r=$ efficiency ratio

$M V P=$ Marginal value product of variable input

$M F C=$ Marginal factor cost (price/unit input)

Based on theory, a firm maximizes its profits with respect to resource use when the ratio of marginal return to the opportunity cost is one. The values can be interpreted as,

If $\mathrm{r}$ is $<1$; resource is excessively over utilized (no scope to increase the resource) hence, decreasing the use of resource increases profit.

If $r>1$; resource is under used (there is a scope to increase the resource use) hence, increasing its rate of use will improve profit level.

If $r=1$; resource is efficiently used, that is optimal utilization of resource hence the point of profit maximization

\section{Data Envelopment Analysis (DEA)}

DEA is a production frontier method and do not need the functional and distributional specification of the model and can incorporate the scale issues. Input orientation method with the assumption of constant returns to scale was employed. This method seeks to minimize input cost to obtain certain level of fixed output. The DEA is used to group the rice farms according their efficiency at the frontier level. This analysis provides insight into the performance rice farms when ARC is compared with CRC.

\section{RESULTS AND DISCUSSION}

\section{Water use efficiency}

The varietal attributes combined with the improved aerobic rice cultivation in unpuddled soil under non-flooded condition contributed to higher physical WUE (Joshi et al. 2009). The physical and economic WUE were higher in aerobic rice cultivation than its conventional counterpart. The physical WUE in aerobic rice was 3.85 quintals per acre inch whereas it was only 1.64 quintals per acre inch in conventional rice cultivation (Table 
1). Hence, 63 per cent of the irrigation water can be saved in aerobic rice compared to conventional rice cultivation. Higher physical WUE was mainly attributed to lower irrigation water used in aerobic rice compared to conventional rice cultivation (Lal et al. 2013). The economic WUE was higher in ARC (₹ 1,644/acre inch) compared to CRC (₹ 269/acre inch). The sustained productivity with lower irrigation water in crops can economize the producers because of reduced imputed cost of irrigation water (Baker, 2020).

Table 1: Water use efficiency under aerobic and conventional rice cultivation

\begin{tabular}{|c|c|c|c|}
\hline $\begin{array}{l}\text { S1. } \\
\text { No. }\end{array}$ & Particulars & $\begin{array}{l}\text { ARC } \\
(n=50)\end{array}$ & $\begin{array}{l}\text { CRC } \\
(n=50)\end{array}$ \\
\hline 1 & $\begin{array}{l}\text { Irrigation water use (acre } \\
\text { inch/ha) }\end{array}$ & 15 & 41 \\
\hline 2 & Main product (q/ha) & 57.76 & 67.31 \\
\hline 3 & $\begin{array}{l}\text { Physical water use efficiency } \\
\text { (q/acre inch) }\end{array}$ & 3.85 & 1.64 \\
\hline 4 & Net returns (₹/ha) & 24653.16 & 11045.72 \\
\hline 5 & $\begin{array}{l}\text { Economic water use efficiency } \\
\text { (₹/acre inch) }\end{array}$ & 1643.54 & 269.41 \\
\hline
\end{tabular}

\section{Resource use efficiency}

Cobb Douglas regression analysis was carried out to find out the factors affecting the Aerobic and conventional rice production and the results are presented in Table 2. The ' $\mathrm{F}$ ' value of the regression was 16.21 and 20.5 in ARC and CRC, respectively and was found significant at one per cent indicating good fit of the model.

\section{Aerobic rice cultivation}

The co-efficient of multiple determination $\left(\mathrm{R}^{2}\right)$ for aerobic rice cultivation was 0.95 indicating that about 95 per cent of variation in the production is explained by the variables considered in the model. The regression co-efficient of human labour, bullock and machine labour, seeds, FYM, fertilizer and irrigation was $0.1902,0.1993,0.0054,0.0619,-0.0411$ and 0.0881, respectively. However, Bullock and machine labour and seeds were found statistically significant at one per cent whereas Human labour and Irrigation were statistically significant at five per cent and the remaining factors like FYM in tractor load and fertilizer were found to be nonsignificant. One unit increase in the input use of human labour, bullock and machine labour, seeds and irrigation above its geometric mean level will lead to increase in gross returns by $0.1902,0.1993$, 0.0054 and 0.0881 units from its geometric mean level. The overall regression model was found to be significant at one per cent.

Table 2: Estimates of the Cobb-Douglas production function in aerobic and conventional rice cultivation

\begin{tabular}{|c|c|c|c|c|}
\hline $\begin{array}{l}\text { Sl. } \\
\text { No. }\end{array}$ & Variables & Parameters & ARC & CRC \\
\hline 1 & Intercept & $a$ & $\begin{array}{l}3.1062^{* *} \\
(10.81)\end{array}$ & $\begin{array}{l}3.3962^{* *} \\
(17.15)\end{array}$ \\
\hline 2 & $\begin{array}{l}\text { Human labour in Man } \\
\text { days }\left(X_{1}\right)\end{array}$ & $b_{1}$ & $\begin{array}{l}0.1902^{*} \\
(2.18)\end{array}$ & $\begin{array}{l}0.3067^{*} \\
(2.33)\end{array}$ \\
\hline 3 & $\begin{array}{l}\text { Bullock and machine } \\
\text { labour in } ₹\left(X_{2}\right)\end{array}$ & $b_{2}$ & $\begin{array}{l}0.1993^{* *} \\
(3.06)\end{array}$ & $\begin{array}{l}0.0826 \\
(1.17)\end{array}$ \\
\hline 4 & Seeds in $\mathrm{kg}\left(X_{3}\right)$ & $b_{3}$ & $\begin{array}{l}0.0054^{* *} \\
(4.78)\end{array}$ & $\begin{array}{l}0.2165^{* *} \\
(3.16)\end{array}$ \\
\hline 5 & $\begin{array}{l}\text { FYM in tractor load } \\
\left(X_{4}\right)\end{array}$ & $b_{4}$ & $\begin{array}{l}0.0619 \\
(1.14)\end{array}$ & $\begin{array}{l}0.3726^{* *} \\
(4.58)\end{array}$ \\
\hline 6 & Fertilizer in $₹\left(X_{5}\right)$ & $b_{5}$ & $\begin{array}{l}-0.0411 \\
(-0.60)\end{array}$ & $\begin{array}{l}-0.0452 \\
(-0.59)\end{array}$ \\
\hline 7 & Irrigation in $₹\left(X_{6}\right)$ & $b_{6}$ & $\begin{array}{l}0.0881^{*} \\
(1.98)\end{array}$ & $\begin{array}{l}0.1238^{*} \\
(2.07)\end{array}$ \\
\hline 8 & $\begin{array}{l}\text { Co-efficient of multiple } \\
\text { determination }\end{array}$ & $R^{2}$ & 0.95 & 0.96 \\
\hline 9 & F value & & $16.21^{* *}$ & $20.5^{* *}$ \\
\hline
\end{tabular}

Note: $1 .{ }^{* *}$ - Significant at 1 per cent; $2 .{ }^{*}$ - Significant at 5 per cent; 3. Figures in parentheses represents ' $t$ ' value.

The ratio of MVP to MFC in case of human labour, bullock and machine labour, seed, FYM, fertilizer and irrigation was $0.49,2.29,1.72,0.55$, -0.79 and 1.10 , respectively. Indicating that, for every additional rupee spent on human labour, bullock and machine labour, seeds and irrigation would give return of ₹ 0.49 , ₹ 2.29 , ₹ 1.72 , and ₹ 1.10, respectively. The ratio of MVP to MFC was less than one for human labour, FYM and fertilizer which imply overutilization of these resources. Hence, there was no scope for using additional units of these factors. Whereas, the ratio of MVP to MFC was more than unity in case of bullock and machine labour, seed and irrigation implying underutilization and hence, there was scope for using additional units of these resources.

\section{Conventional rice cultivation}

The co-efficient of multiple determination $\left(\mathrm{R}^{2}\right)$ 
was 0.96 indicating that, about 96 per cent of the variation in the production of conventional rice is explained by the variables considered in the model. The regression co-efficient of human labour, bullock and machine labour, seeds, FYM, fertilizer and irrigation was $0.3 .67,0.0826,0.2165,0.3726$, -0.0452 and 0.1238 , respectively. However, seeds and FYM were found statistically significant at one per cent whereas Human labour, and Irrigation were statistically significant at five per cent and the remaining factors like Bullock and machine labour and fertilizer were found to be non-significant (Nasurudeen and Mahesh, 2004). One unit increase in the input use of human labour, seeds, FYM and irrigation above its geometric mean level will lead to increase in gross returns by $0.3067,0.2165,0.3726$ and 0.1238 units from its geometric mean level. The overall regression model was found to be significant at one per cent. Human labour, seeds and irrigation were the major factors found significant in both ARC and CRC because these factors were used intensively in cultivation of rice by sample farmers.

The ratio of MVP to MFC was less than one in case of human labour (0.89), bullock and machine labour (0.65), seed (0.87) and irrigation (0.85), indicating that an expenditure of one rupee on of human labour, bullock and machine labour, seed and irrigation gives only ₹ 0.89 , ₹ 0.65 , ₹ 0.87 and ₹ 0.85 , respectively. Hence, there was no scope for using additional unit of the input implying overutilization of these factors. The negative ratio for fertilizer $(-0.75)$ indicated that fertilizer was used at higher level than necessary resulting in loss. The ratio was greater than unity for FYM (2.56) suggesting that an investment of one rupee would give additional gross return of ₹ 2.56 (Sunandini et al. 1993) and there was scope for using additional units of FYM since it was underutilized (Table 3).

\section{Comparison of resource use efficiency in ARC Vs. CRC}

Conservation agriculture and sustainable agricultural practices are intended to enhance farm income without compromising productivity and RUE. Sustainable improved technologies in rice cultivation can increase the profitability, RUE and reduce irrigation requirement and global warming potential (Hanuman et al. 2020). ARC is a promising technology in the field when compared to conventional rice cultivation from the results of RUE. The ratio of MVP to MFC was less than unity for human labour in both ARC (0.49) and CRC (0.89). Hence, there was no scope for additional use implying overutilization of human labour. The labour requirement is high during transplanting and harvesting in rice cultivation because of prevailing traditional manual method (Balasubramanian and Hill, 2002). The higher labour requirement in aerobic rice was due to problem of weeds in direct seeded rice where rice and weed seedlings emerge simultaneously and absence of standing water to suppress weeds (Nirmala et al. 2016). In case of bullock and machine labour, the ratio was more than one in aerobic (2.29) implying underutilization whereas, in conventional (0.65) it was less than one indicating overutilization. There was scope for additional use of bullock and machine labour in ARC which implies that, better utilization of

Table 3: Resource use efficiency in ARC Vs. CRC (per ha)

\begin{tabular}{|c|c|c|c|c|c|c|c|c|c|c|}
\hline \multirow[b]{2}{*}{ Variables } & \multicolumn{5}{|c|}{$\operatorname{ARC}(n=50)$} & \multicolumn{5}{|c|}{ CRC $(n=50)$} \\
\hline & $\begin{array}{l}\text { Input use at } \\
\text { geometric } \\
\text { mean level }\end{array}$ & $\begin{array}{l}\text { Co- } \\
\text { efficient }\end{array}$ & MVP & MFC & $\begin{array}{l}\text { MVP/ } \\
\text { MFC }\end{array}$ & $\begin{array}{l}\text { Input use at } \\
\text { geometric } \\
\text { mean level }\end{array}$ & $\begin{array}{l}\text { Co- } \\
\text { efficient }\end{array}$ & MVP & MFC & $\begin{array}{l}\text { MVP/ } \\
\text { MFC }\end{array}$ \\
\hline $\begin{array}{l}\text { Human labour } \\
\text { (Man days) }\end{array}$ & 30.74 & $0.19^{*}$ & 198.54 & 400 & 0.49 & 46.35 & $0.31^{*}$ & 357.90 & 400 & 0.89 \\
\hline $\begin{array}{l}\text { Bullock and } \\
\text { Machine labour } \\
\text { (Hrs.) }\end{array}$ & 2780.48 & $0.19^{* *}$ & 2.29 & 1 & 2.29 & 6874.25 & 0.08 & 0.65 & 1 & 0.65 \\
\hline Seed $(k g)$ & 9.23 & $0.01^{* *}$ & 18.94 & 11 & 1.72 & 38.38 & $0.01^{* *}$ & 20.85 & 24 & 0.87 \\
\hline FYM (tractor load) & 1.20 & 0.06 & 1652.09 & 3000 & 0.55 & 2.62 & $0.37^{* *}$ & 7687.39 & 3000 & 2.56 \\
\hline Fertilizer (₹) & 1653.66 & -0.04 & -0.79 & 1 & -0.79 & 3267.82 & -0.05 & -0.75 & 1 & -0.75 \\
\hline Irrigation (₹) & 6.87 & $0.09^{*}$ & 411.50 & 372 & 1.10 & 23.01 & $0.12^{*}$ & 290.89 & 342 & 0.85 \\
\hline
\end{tabular}

Note: 1 . ${ }^{*}$ - Significant at 1 per cent; $2{ }^{*}$ - Significant at 5 per cent. 
machine labour further optimizes the production and helps in maximizing profit (Ravi et al. 2016). The seed was underutilized in aerobic (1.72) compared to conventional (0.87) which was evident from MVP to $\mathrm{MFC}$ ratio. Hence, there was scope for additional allocation of seeds in ARC as opposed to no scope in CRC. FYM was underutilized in conventional (2.56) compared to aerobic (0.55) where it was over utilized. The CRC farmers had scope for increasing the use of FYM. Fertilizer used at higher level than necessary in aerobic (-0.79) as well as conventional rice cultivation $(-0.75)$ which indicate any additional use of fertilizer would incur loss to the farmers. The ratio was more than unity for irrigation in aerobic (1.10) indicating underutilization whereas it was less than unity in conventional (0.85) indicating overutilization of irrigation water. These findings are in similar line with study conducted by Manohar, Y. (2017), aptly support the above results. The aerobic farmers had scope for additional use of irrigation water which would increase their profit. The ARC farmers had scope for additional use of bullock and machine labour, seed and irrigation which were found to be statistically significant. The conventional rice cultivation farmers had scope for additional use of FYM only to increase their returns (Table 3).

\section{Technical, Allocative and Economic efficiency in ARC and CRC farms}

Technical, allocative and economic efficiency levels of each farm were estimated by Data Envelopment Analysis (DEA) separately for ARC and CRC farms. The criterion used by Ferreira (2005) was adopted in the present study to decide the cut- off score for efficient farms. Farms which had a score of 0.90 and above were considered as efficient farms.

The results of technical efficiency are presented in Table 4. It can be seen that average technical efficiency score was more in ARC farms (0.937) compared to CRC farms (0.906). In ARC, majority of farms $(74 \%)$ showed technical efficiency score $>0.90$ followed by CRC (54\%). Comparing technical efficiency range, ARC farms were more technically efficient than CRC farms. Allocative efficiency scores of the ARC and CRC farms revealed that, only 26 and 24 per cent of the farms were allocatively efficient $(>0.90)$ in ARC and CRC, respectively. The average allocative efficiency score was high in ARC farms (0.863) as compared with CRC farms (0.839). Allocatively inefficient means the scarce resources are not being employed in more optimal way so as to increase the profitability and decrease the cost. The results indicated that, even though the farmers are more technically efficient but are allocatively inefficient which calls the attention of the policy makers to make the farmers allocatively efficient (Table 4).

Table 4: Distribution of rice farms under technical, allocative and economic efficiency

\begin{tabular}{lllll}
\hline Particulars & \multicolumn{2}{l}{ ARC $(\mathbf{n}=\mathbf{5 0})$} & \multicolumn{2}{l}{ CRC ( $\mathbf{n = 5 0 )}$} \\
\hline \multicolumn{2}{l}{ Technical efficiency } & & & \\
\hline TE Score & No. & Per cent & No. & Per cent \\
\hline$<0.45$ & 0 & 0 & 0 & 0 \\
0.45 to 0.60 & 0 & 0 & 0 & 0 \\
0.60 to 0.75 & 0 & 0 & 1 & 2 \\
0.75 to 0.90 & 13 & 26 & 22 & 44 \\
$>0.90$ & 37 & 74 & 27 & 54 \\
\hline
\end{tabular}

\begin{tabular}{lllll}
\hline \multicolumn{2}{l}{ Average TE Score } & 0.937 & \multicolumn{2}{l}{0.906} \\
\hline \multicolumn{2}{l}{ Allocative efficiency } \\
\hline AE Score & No. & Per cent & No. & Per cent \\
\hline$<0.45$ & 0 & 0 & 0 & 0 \\
0.45 to 0.60 & 0 & 0 & 0 & 0 \\
0.60 to 0.75 & 2 & 4 & 0 & 0 \\
0.75 to 0.90 & 35 & 70 & 38 & 76 \\
$>0.90$ & 13 & 26 & 12 & 24 \\
\hline
\end{tabular}

\begin{tabular}{lllll}
\hline Average AE Score & 0.863 & \multicolumn{3}{l}{0.839} \\
\hline Economic efficiency & & & \\
\hline EE Score & No. & Per cent & No. & Per cent \\
\hline$<0.45$ & 0 & 0 & 0 & 0 \\
0.45 to 0.60 & 0 & 0 & 0 & 0 \\
0.60 to 0.75 & 4 & 8 & 4 & 8 \\
0.75 to 0.90 & 38 & 76 & 42 & 84 \\
$>0.90$ & 8 & 16 & 4 & 8 \\
\hline
\end{tabular}

Average EE Score $\quad 0.809 \quad 0.761$

It can be observed that only a small percentage of the farms were economically efficient $(>0.90)$ in both ARC and CRC (16\% and $8 \%$, respectively). The average economic efficiency score was 0.809 and 0.761 in ARC and CRC, respectively indicating that ARC farms were more economically efficient compared to CRC farms.

\section{CONCLUSION}

The sustainability in the context of modern 
agriculture is a key issue to be addressed in all the policy implications of a new technology. The development of a new variety has to be assessed for the positive impact on farm income in line with the sustainable practices. The efficiency analysis of aerobic rice in comparison with conventional rice cultivation provided positive insight into the technology. The higher technical, allocative and economic efficiency in ARC highlights the superiority of the technology over CRC. The higher efficiency and better income from aerobic rice plays vital role in advertising the technology for further wide spread adoption of this technology and shifting from conventional to aerobic in water distress rice growing regions. The aerobic rice will be promising technology considering results of the study and it helps other stakeholders in refining the technology and bringing better sustainable policies. The superior physical and economic water use efficiency in aerobic rice cultivation paves way for the adoption of this technology under tube well irrigated area where irrigation water is very scarce. The resources were efficiently utilized in ARC compared to CRC. There is scope to increase the returns in ARC by additional input use and optimal resource allocation. The study claim the crucial role of sustainable agriculture in reducing greenhouse gas emissions as well as conserving energy and water. For a planet that is increasingly facing the vagaries of climate change, sustainable cultivation provides resilience because it focuses on growing crops efficiently while ensuring that the soils are healthy and with less water requirement. Additionally, the aerobic rice will play a key role in sinking the carbon footprint and dependence on enormous irrigation. Though the study tries to be comprehensive in its scope, there are few limitations inherent in it. Due to the limitation of time and other resources, the study was confined to Eastern dry zone of Karnataka. The identification of respondents was cumbersome since ARC farmers were limited and scattered. The aerobic rice cultivation technology is in developing stage hence result may partially reflect the actual situation. Further, the opinion expressed by the respondents with regard to the various variables of the study may not be totally free from personal bias and prejudice. Hence, the results of the study cannot be generalized beyond the limits of the study area.

\section{ACKNOWLEDGEMENTS}

The study was carried out as part of Master's work in collaboration with the authors. The authors profusely thank the stakeholders of the aerobic rice technology development for sharing required information on cultivation practices, data on sample farmers and identification of core problems in rice cultivation. We also would like show our gratitude to the farmers who were enthusiastic in sharing the field data of production with the researchers. We are immensely grateful to professors of department of agricultural economics, UAS, Bangalore for helping in refining methodology and results for the best outcome.

\section{REFERENCES}

Ashok, M.T. 2018. Economic analysis of conjunctive use of irrigation water in Malaprabha command area of Karnataka, M.Sc (Thesis). University of Agricultural Sciences, Bangalore.

Balasubramanian, V. and Hill, J.E. 2002. Direct seeding of rice in Asia: emerging issues and strategic research needs for the $21^{\text {st }}$ century. Environ. Sci., pp. 15-42.

Bouman, B.A.M., Yang, X., Wang, H., Wang, Z., Zhao, J. and Wang C.C.B. 2002, Aerobic rice (Han Dao): A new way of growing rice in water-short areas, International Soil Conservation Organization Conference, Beijing, China. Tsinghua University Press, pp. 175- 181.

Bouman, B.A.M., Yang, X., Wang, H., Wang, Z., Zhao, J. and Chen, B. 2006, Performance of aerobic rice varieties under irrigated conditions in North China. Field Crops Res., 97(1): 53-65.

FAO, 2018. FAOSTAT database collections. Food and Agriculture Organization of the United Nations. Food outlook biannual report on global food markets. Rome.

Ferreira, M.A.M. 2005. Technical and scale efficiency of cooperatives and capital companies in the dairy industry in Brazil. Ph.D. Thesis, Federal University of Viçosa, Brazil.

Hanuman, S.J., Kumar, V., Datta, A., Choudhary, M., Singh, Y., Suresh K. Kakraliya, Poonia, T., Andrew J. McDonald, Mangi L. Jat and Parbodh C. Sharma, 2020. Designing profitable, resource use efficient and environmentally sound cereal based systems for the Western Indo-Gangetic plains, Scientific report 10, Nature, pp. 10-54.

Jayasree, K., Michael, B., Rajesh, K.R. and Kadambot, H.M.S. 2021. Sustainability of Traditional Rice Cultivation in Kerala, India - A Socio-Economic Analysis, Sustainability, 13(980): 1-16.

Joshi, R. and Kumar, P. 2012. Aerobic rice: an option for growing rice under limited water availability. Indian Farm., 62(2): 11-14.

Joshi, R., Singh, B. and Shukla, A, 2018. Evaluation of elite rice genotypes for physiological and yield attributes under 
aerobic and irrigated conditions in tarai areas of western himalayan region. Cur. Plant Biol., 13: 45-52.

Joshi, R., Mani, S.C., Shukla, A. and Pant, R.C. 2009. Aerobic rice: water use sustainability. Oryza, 46(1): 1-5.

Ladha, J.K., Pathak, H. and Gupta, R.K. 2009. Sustainability of the rice-wheat cropping system: issues, constraints and remedial options. J. Crop Improve., 19(2): 125-136.

Lal, B., Nayak, A.K., Priyanka, G., Rahul, T., Singh, T. and Katara, J.L. 2013. Aerobic Rice: A water saving approach for rice production. Popular Kheti, 1(2): 1- 4.

Maneepitak, S., Ullah, H., Paothong, K., Kachenchart, B., Datta, A. and Shrestha, R.P. 2019. Effect of water and rice straw management practices on yield and water productivity of irrigated lowland rice in the Central Plain of Thailand. Agric. Water Manag., 211: 89-97.

Manohar, Y. 2017. A Comparative economics of transplanted and direct seeded rice (DSR) cultivation in Tungabhadra project command area of Karnataka, MSc (Agri.) Thesis, PJTSAU, Telangana.

Nasurudeen, P. and Mahesh, N. 2004. Impact of technology on paddy farms in Karaikal region of Union Territory of Pondicherry. Agric. Econ. Res. Rev., 17: 43-50.

Nie, L., Peng, S., Bouman, B.A.M., Huang, J., Cui, K., Visperas, R.M. and Park, H.K. 2007. Alleviation of soil sickness caused by aerobic monocropping: growth response of aerobic rice to soil oven heating. Plant Soil, 300: 185-195.

Nirmala, B., Amtul, W. and Muthuraman, 2016. Direct seeded rice: An impact analysis in Tungabhadra command area of Karnataka. Indian Res. J. Ext. Edu., 16(2): 51-54.
Ravi, S.C., Umesh, K.B. and Bellundagi, V. 2016. Economic Analysis of Yield Gap and its Implication on Profitability of Finger Millet (Eleusine coracana L.) Production in Karnataka, Int. J. Bio-res. Stress Manag., 7(2): 286-290.

Singh, B., Shefali, M., Deepak, S. and Joshi, B. 2021. Growing Rice with Less Water: Improving Productivity by Decreasing Water Demand, Rice improvement, pp. 147-170.

Schroeder, J.I., Delhaize, E, Frommer, W.B., Guerinot, M.L., Harrison, M.J., Herrera-Estrella, L., Horie, T., Kochian, L. V., Munns, R., Nishizawa, N.K. and Tsay, Y.F. 2013. Using membrane transporters to improve crops for sustainable food production. Nature, 497(7447): 60-66.

Shailaja, H. and Shivashankar, G. 1985. Genetical studies of rice under suboptimal conditions, $P h$. D. Thesis, University of Agricultural Sciences, Bangalore.

Shailaja, H. 2008. MAS, 26, a new aerobic rice variety for water saving and safe environment. Aerobic rice cultivation Brochure, MAS lab, University of Agricultural Sciences, Bangalore.

Sunandini, Parthasarathi, P.B. and Reddy, Y.V.R. 1993. Resource productivity and resource use efficiency on paddy farms of Andhra Pradesh. Agric. Situation in India, 47(6): 835-840.

UASB, 2017. Package of Practice of field crops, University of Agricultural Sciences, Bangalore, pp. 67-71.

Venkataravana, P. 1991. Studies on genetic variability, character association and path co-efficient analysis in F2 segregating of Rice (Oryza sativa L.) under irrigated and aerobic conditions, M.Sc. Thesis, University of Agricultural Sciences, Bangalore. 